\author{
مديريت بهينه آب متناسب با تغييرات اقليمى در دشت اروميه \\ ساناز مقيم" و جواد رحمانى

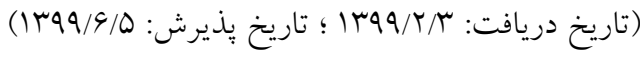

جكيده

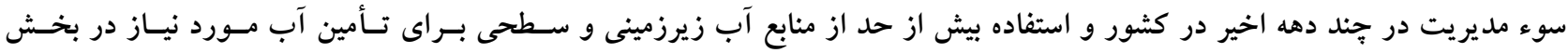

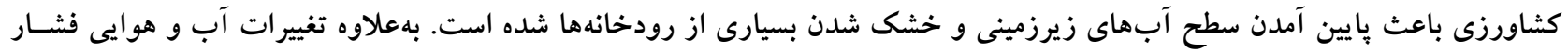

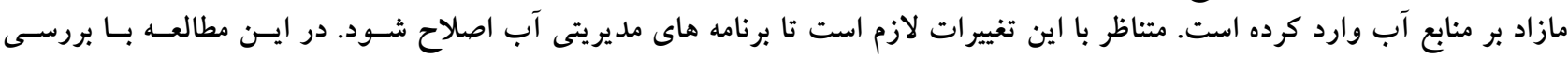

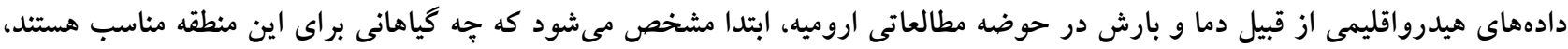

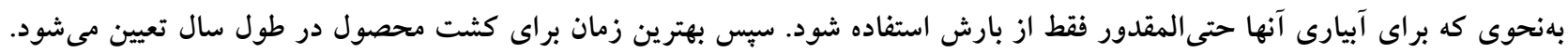

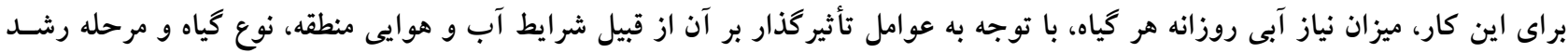

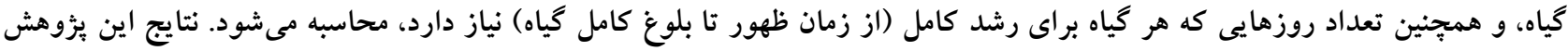

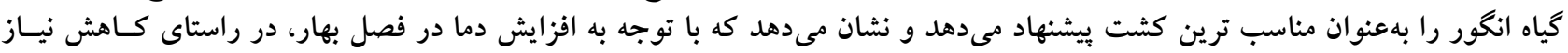

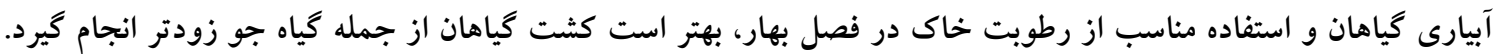

وازههاى كليدى: مديريت بهينه آب، تغيير اقليم، كشاورزى، الكوى كشت، دوره رشد گياه، نياز آبى

1. گروه مهندسى آب و محيط زيست، دانشكده مهندسى عمران، دانشگاه صنعتى شريف، تهران، ايران

moghim@sharif.edu :مسئول مكاتبات: يست الكترونيكى مهنى 
منابع آبى را نمايانت تر كـرده اسـت. امـروزه بـا رشـــ روزافـزون

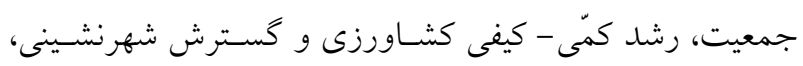

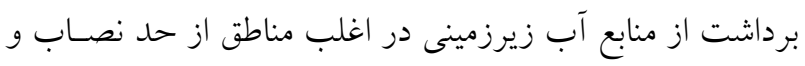

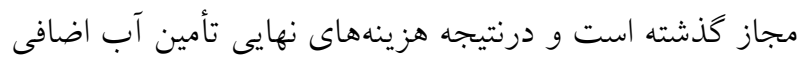

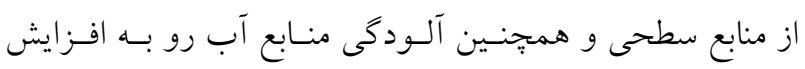

(19) - 2) (19)

در جنـلد دهه اخير دماى هوا در اكثر نقـاط دنيـا داراى رونــــ

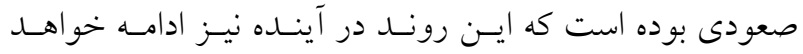

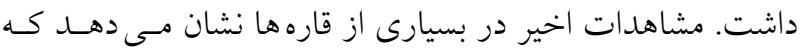
اين روند افزايشى دما بهصورت طبيعى نيز بر يوششهاى كياهى

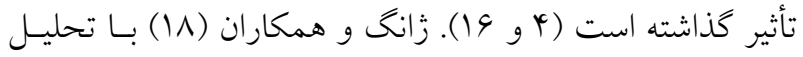
تصاوير سنجنده ماديس به بررسى تغييـرات فنولـوزى كياهـان

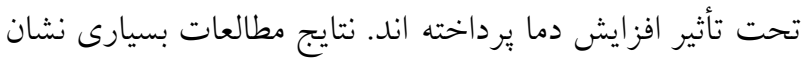

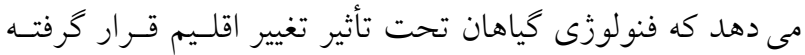

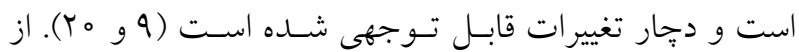
طرفى فنولوزى كياه يكى از مهم ترين شاخصه هاى كياه است كه

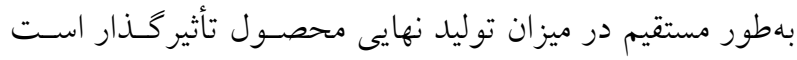

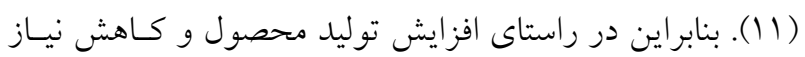
آبيارى لازم است كه زمـان كشـت محصـولات كشـاورزى نيـز

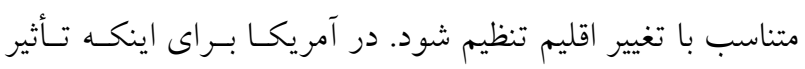

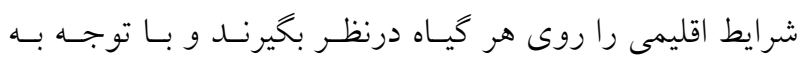
شرايط اقليمى، گياه مناسب را انتخاب كنند مطالعاتى انجام شده رده

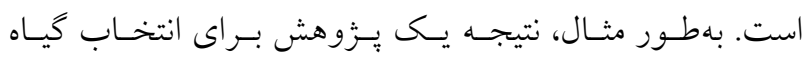

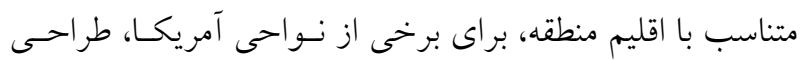

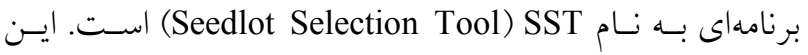

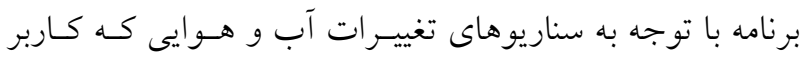

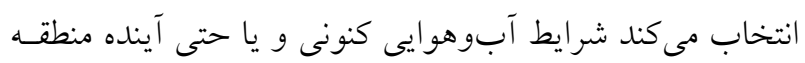

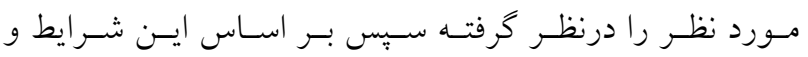

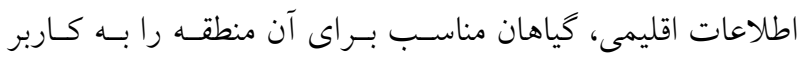
بيشنهاد مى دهد (4). هدف از اين مطالعـه ايسن اسـت كـه در راسـتاى مـديريت صحيح منابع آب، با بررسى دادههاى هيدرواقليمى از قبيل دما و

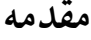

بحران آب يكى از معضلات جـدى در جهـان اسـت. جمعيـت

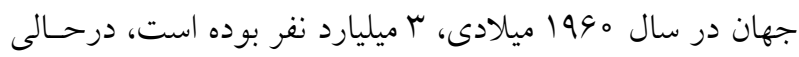

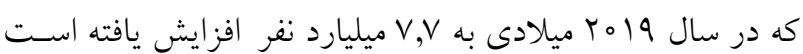

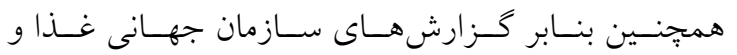

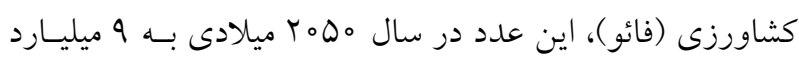

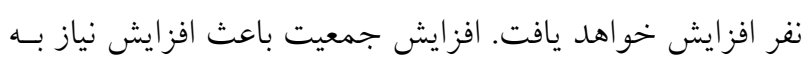

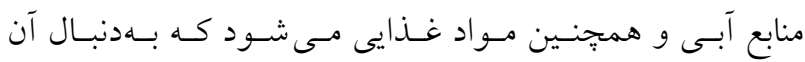

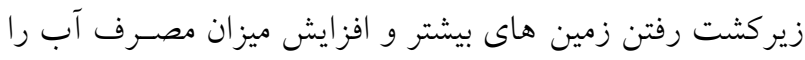

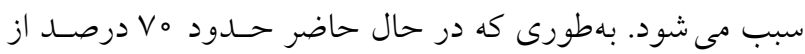

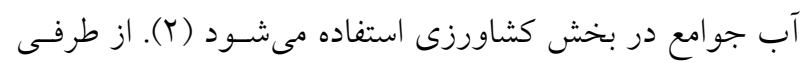

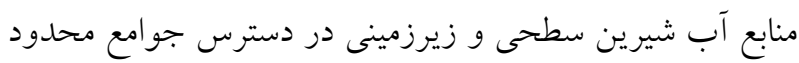

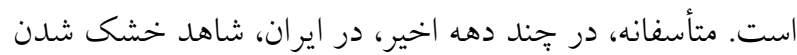
تدريجى منابع آب سطحى و زيرزمينى هستيم. يكى از مهمترين

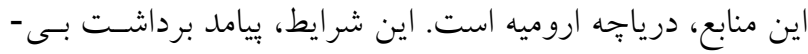
رويه از منابع آبى، توسعه بخش كشاورزى و كاشت محصصولات با نياز آبى بالا در يكى منطقه بدون توجه به شرايط اقليمى مـورد ابله نياز هر كشت است. از طرف ديخر كشاورزى يكى از مهمتـرين

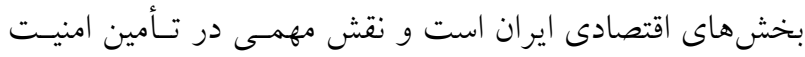
غذايى و اشتغالز ايى دارد. اين بخش سهم عمدهاى از صهاد إدرات غيرنفتى را بهخود اختصاص داده است و نقش تعيـين كنتـدهاى

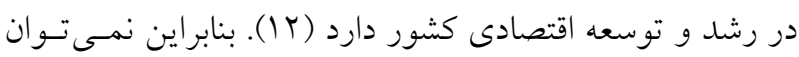

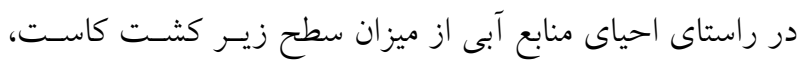

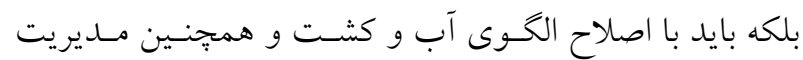

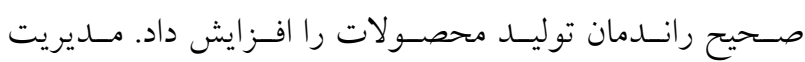

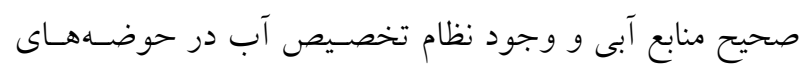

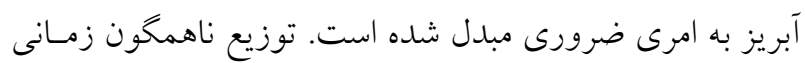

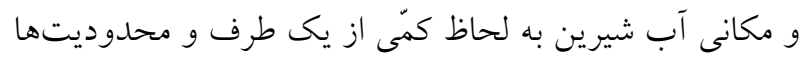

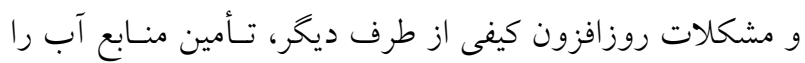

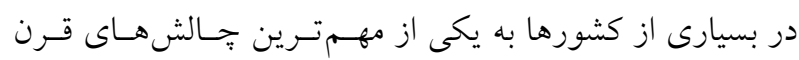

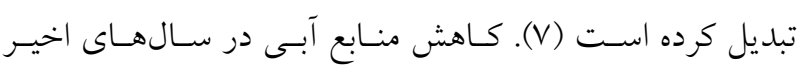

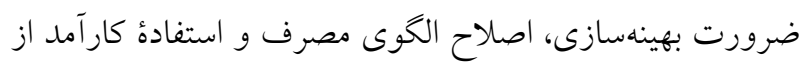


جدول ا. ميانگين نياز آبى روزانه گياه مرجع در دوره رشد (ميلىمتر) (r)

\begin{tabular}{|c|c|c|c|}
\hline بيشتر از rQ درجه سانتى گراد & بين هاى متوسط روزانه & كمتر از ها درجه سانتى گراد & منطقه اقليمى \\
\hline $10-9$ & $\Lambda-\vee$ & $9-4$ & خشك \\
\hline $9-\wedge$ & $V-4$ & $\Delta-\varphi^{r}$ & نيمهاخشك \\
\hline$\wedge-\vee$ & $9-0$ & $\mu-r$ & نيمه مرطوب \\
\hline $9-0$ & $r-r$ & $r-1$ & 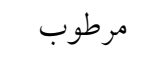 \\
\hline
\end{tabular}

رشد كياه تغيير مى كند. شرايط اقليمس بـهــور مسـتقيم بــر

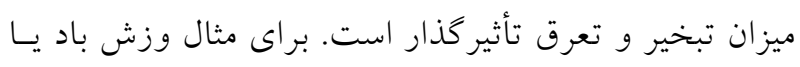

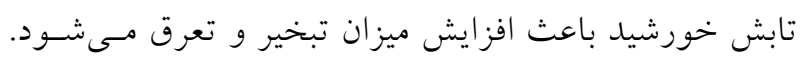

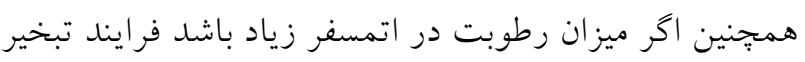
و تعرق سخت تر خواهد شد و از ميزان آن كاستهـ مسى شئسود.

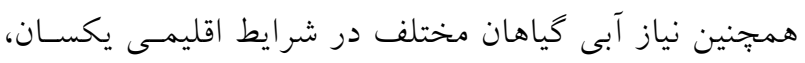
متفاوت است. در اين يـرّوهش بـر اسـاس بيشــهاد سـازمان

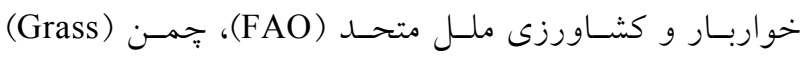

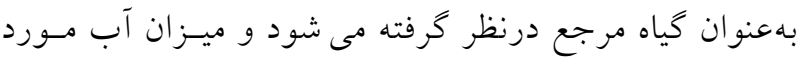

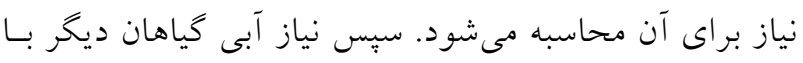

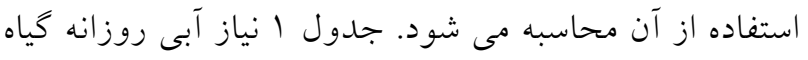

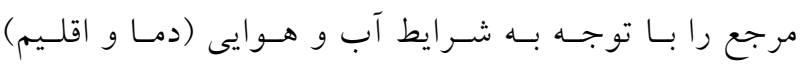
مشخص مى كند (r).

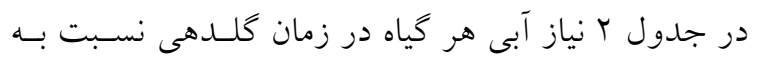

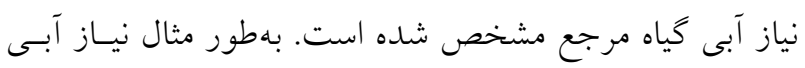

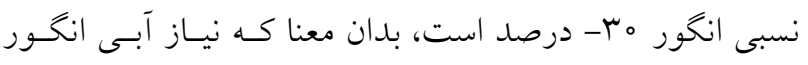

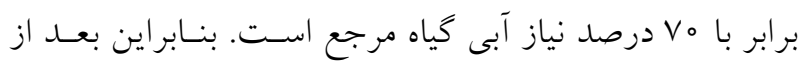

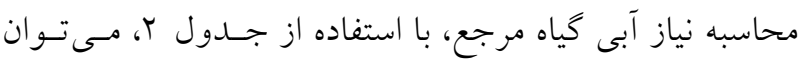

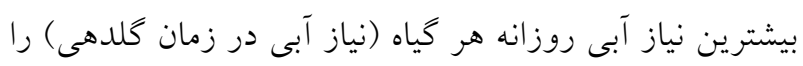
محاسبه كرد (r) (r).

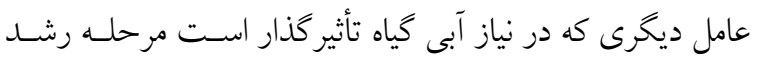
كياه است. زمانى كه كياه تـازه جوانـه زده اسـت و در مراحسل اول فئل

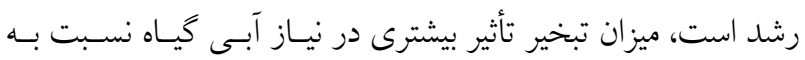
تعرق دارد. زمانى كه كياه رشد مى كند اهميت تعرق بيشتر مى نشـود. شكل ا مراحل مختلف رشد يك كياه را نمايش مىدهد (r) دمان.
بارش در حوضه مطالعاتى اروميه مشخص شـود كـهـ ابتــا جـهـ

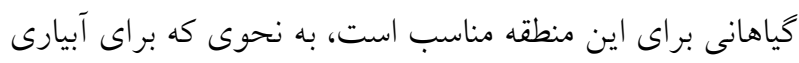
آنها تا جايى كه ممكن است فقط از بارش استفاده شـود و نيـاز

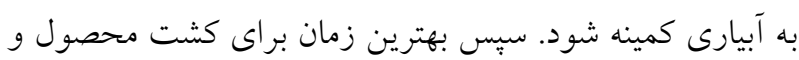

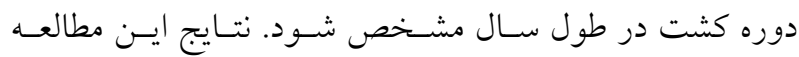
مستقل از جنس خاك و سيستم آبيارى است و فرض شده است

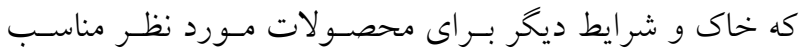

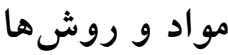

دو نياز اساسى كياه براى رشد مناسب، عبارتند از نياز آبى و نياز

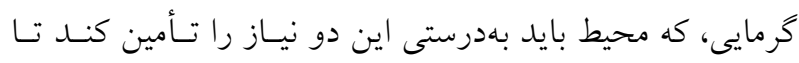
رشد كياه كامل شود. انتخاب بهترين زمان كشت كياه با توجه به به بهان

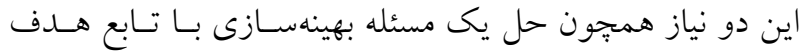

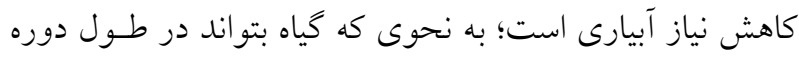

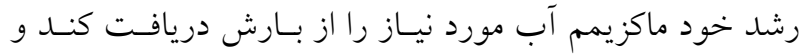

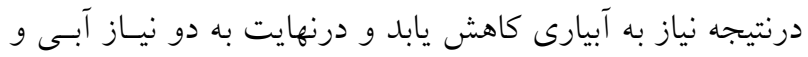

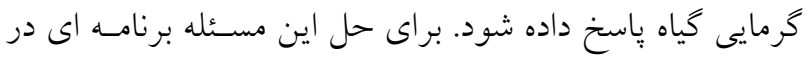

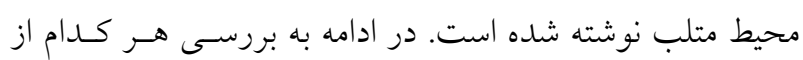

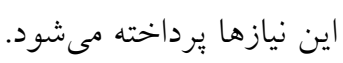
نياز آبى گياه

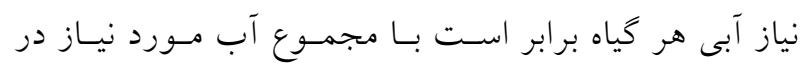
بخش تبخير و تعرق (Evapotranspiration) كه تحت تـأثير

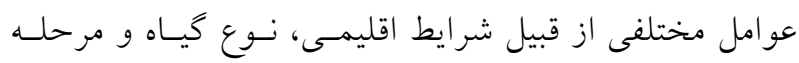


جدول r. مقايسه نياز آبى روزانه هر گياه در زمان گلدهى با نياز آبى گياه مرجع (r)

\begin{tabular}{|c|c|c|c|c|}
\hline$+\% \varphi_{0}$ & $+\%$ 。 & به اندازه كياه مرجع & $-\% 10$ & $-\%$. \\
\hline نيشكر & 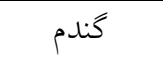 & هويج & خيار & انكور \\
\hline \multirow[t]{9}{*}{ برنج } & لوبيا & كاهو & كدو ك & زيتون \\
\hline & ذرت & اسفناج & & \\
\hline & جغندقند & 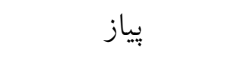 & & \\
\hline & عدس & جاى & & \\
\hline & نخود & 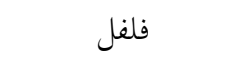 & & \\
\hline & جو & & & \\
\hline & كوجه & & & \\
\hline & آفتاب كردان & & & \\
\hline & سيب زمينى & & & \\
\hline
\end{tabular}

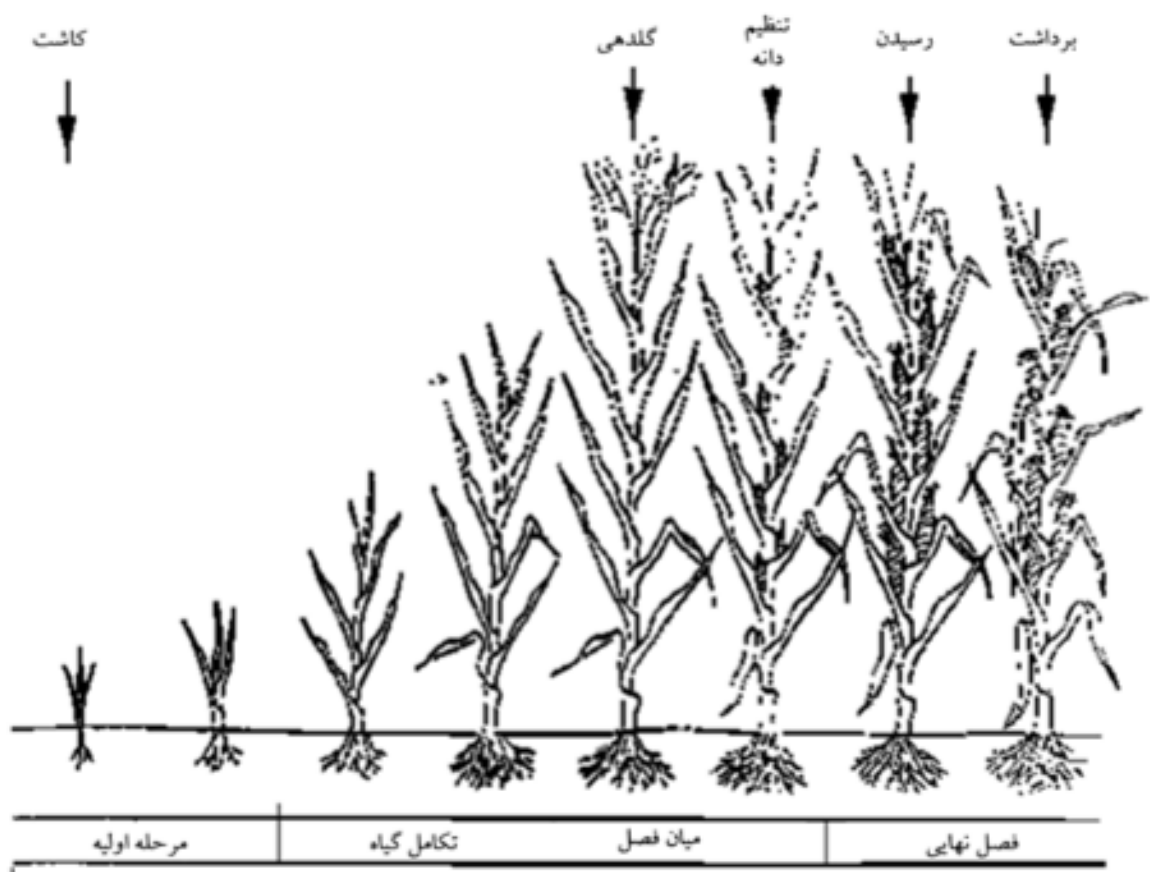

شكل 1. مراحل رشد يك گياه (r)

نياز آبى گياه در مرحله ميانفصل مىشود. در فصل نهايى ( Late (season

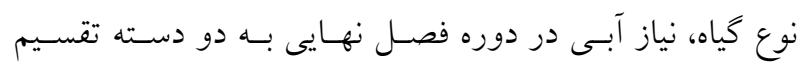

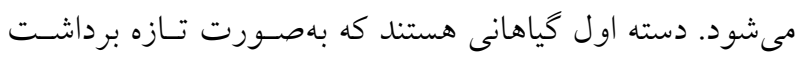
مىشوند مثل كاهو، كلم. در اين دسته مشاهده مىشود كـه نيساز

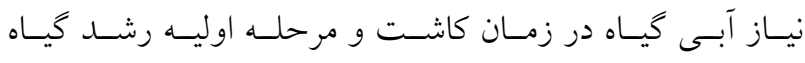
(Initial stage) (Mid-season)

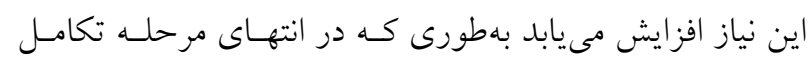

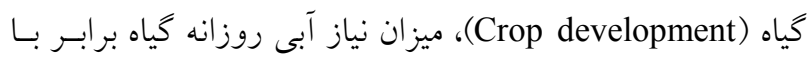




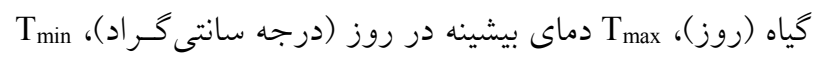

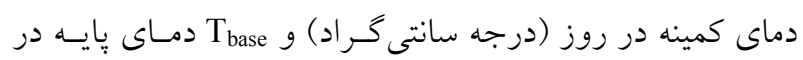

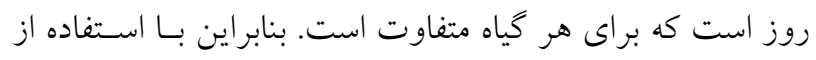

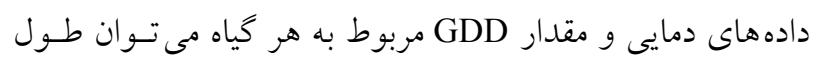
دوره رشد كياه از زمان ظهور تا بلوغ را معار ماسبه كرد.

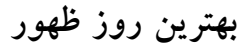
براى يافتن بهترين روز ظهـور كيـاه، ابتـدا هـر روز از سـال

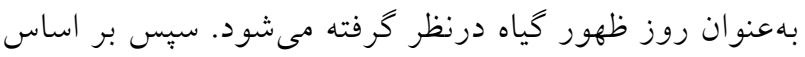
مقدار GDD آن گياه، طول دوره رشد كياه محاسبه مى شـودود.

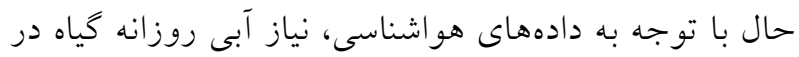

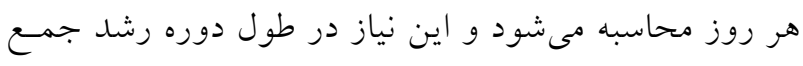

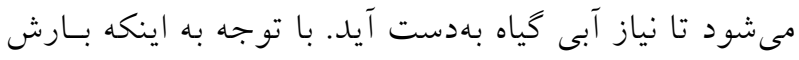

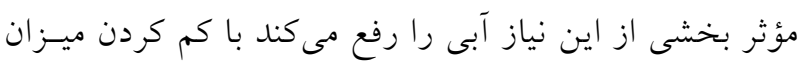

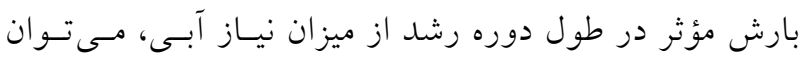

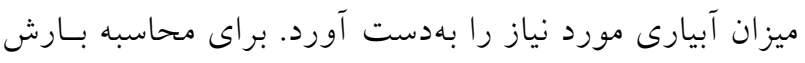

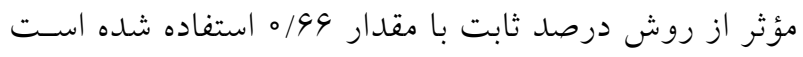

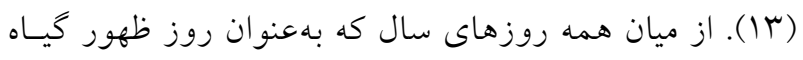
درنظر كرفته شده اند، روزى كه منجر به كمترين نياز آبيـارى شود به عنوان بهترين روز ظهور گياه درنظر كرفته مسى شـود.

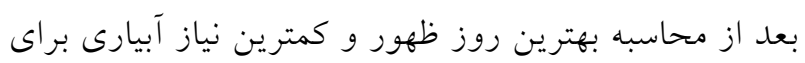

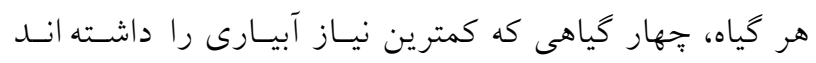
بهعنوان كياهان مناسب درنظر مي كيريم.

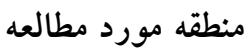

منطقــهُ مــورد مطالعـه، دشـت اروميـهـ (شـكل r) بــا مسـاحت

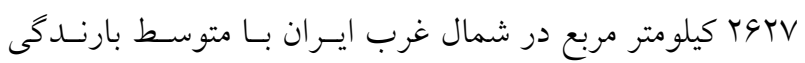

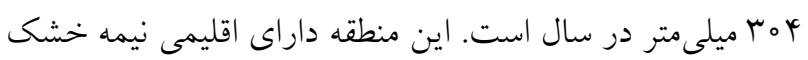
است (^). متوسط بِتانسيل تبخير و تعرق سالانه در منطقـه بـين

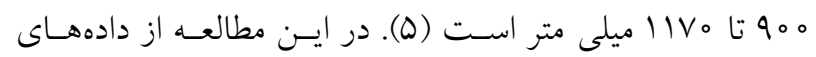

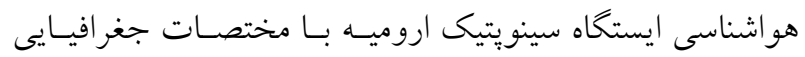

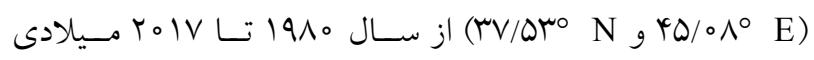

آبى گياه در مرحله نهايى به اندازه نياز آبى كياه در مرحله رشـــ

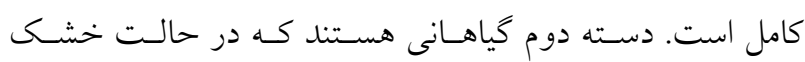

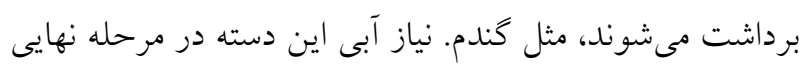

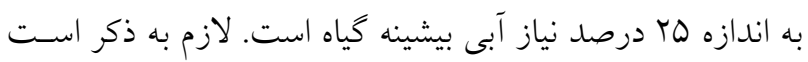

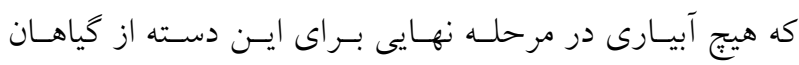

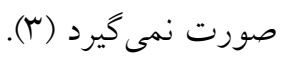
بدين ترتيب با داشتن اطلاعاتى درباره دما و اقليم منطقه

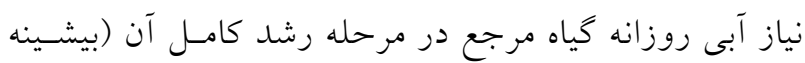

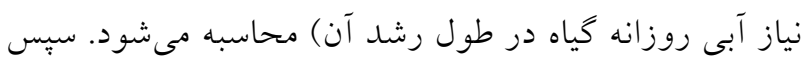

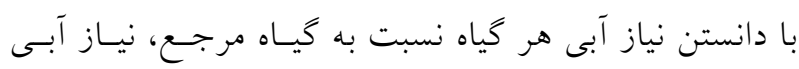

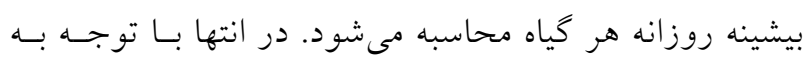

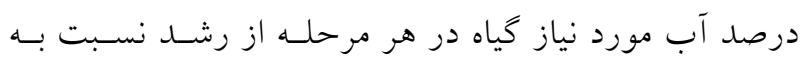

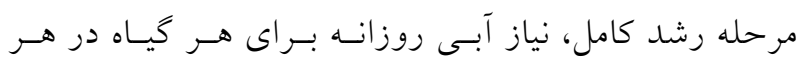
مرحله محاسبه مىشود.

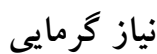

همان طور كه توضيح داده شـــ بـا اسـتفاده از نيـاز آبـى گيـاه و

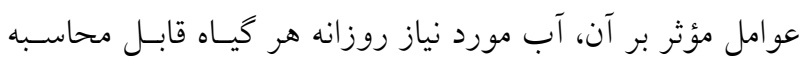

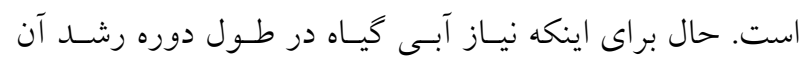

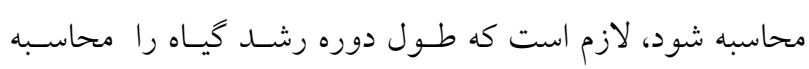

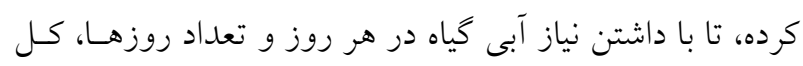

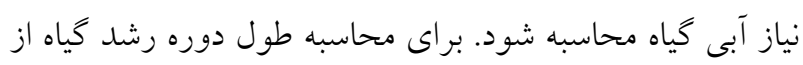
نياز خرمايى كياه استفاده شده است.

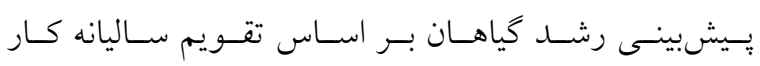

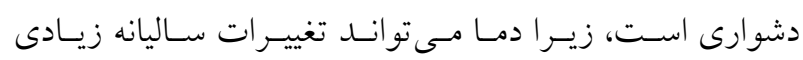

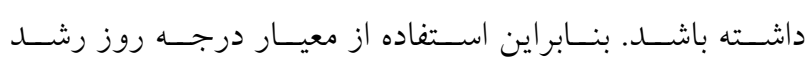
Growing Degree Days)

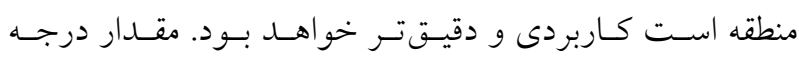

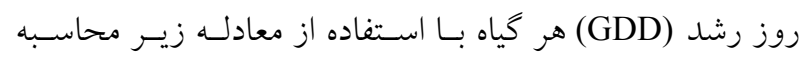

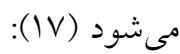
$\mathrm{GDD}=\sum_{1}^{\mathrm{n}}\left(\frac{\mathrm{T}_{\max }+\mathrm{T}_{\min }}{2}-\mathrm{T}_{\text {base }}\right)$ در معادله فوق، n طول دوره رشد گياه از زمان ظهـور تـا بلـوغ 


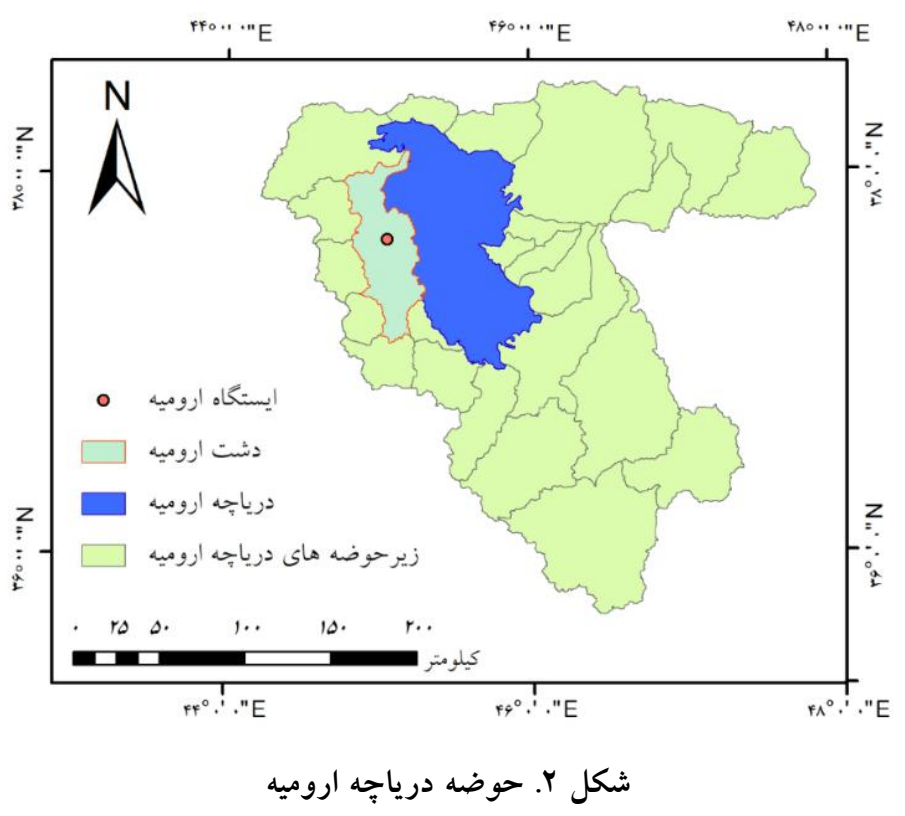

روند نزولى در بهترين زمان ظهور كياه مشاهده مىشود، كَاه ايـن

كاهش شديدتر و كاه با شيب كمترى انجام مى گيرد.

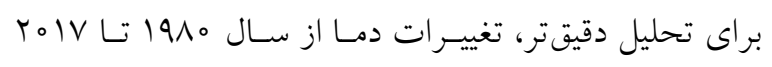

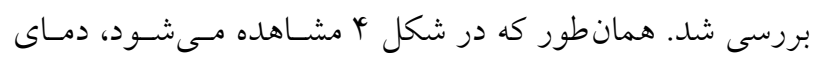

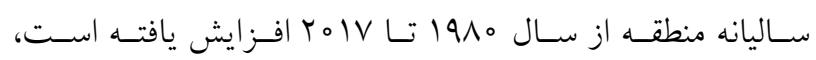

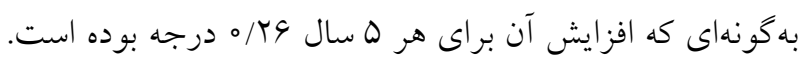

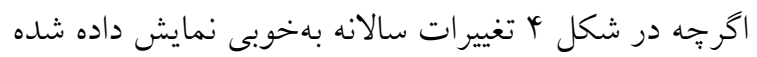
است، اما تغييرات فصلى در هر سال بهخـوبى ديــده نمسى شـود. بنابر اين براى مشـاهده ايـن تغييـرات از ميـانخين دمـاى ماهانـهـ (شكل ه) استفاده شده است. همان طور كه در شكل هـ مشـاهده مىشـود، در فصـل زمسـتان، در سـالهـاى مختلـف، تغييـرات

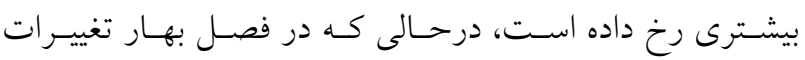

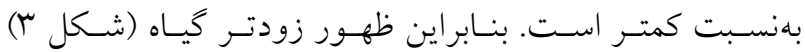

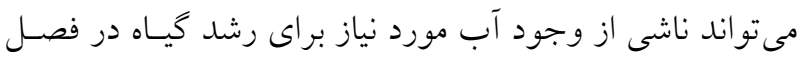
بهار باشد و درنتيجه اين نياز گرمايى كياه است كه كنترل كنتسه.

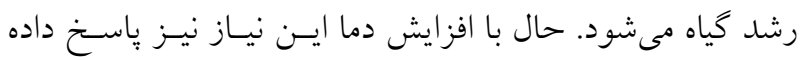

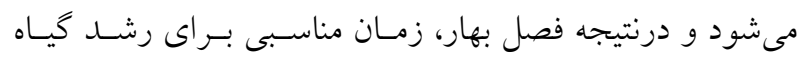

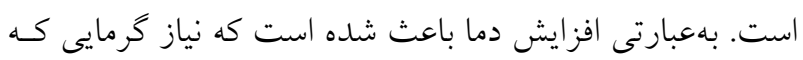

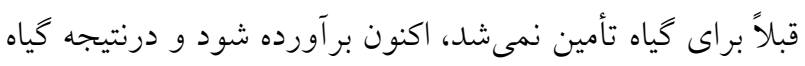
زودتر ظهور كند.
جدول r خلاصهاى از نتايج اين يزوهش در دشت اروميه بـراى

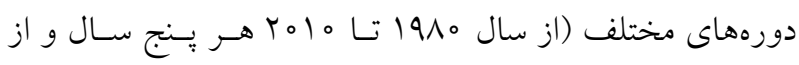

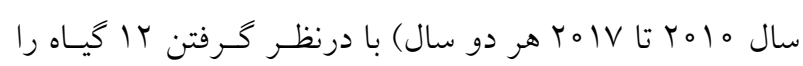
نمايش مى مهد.

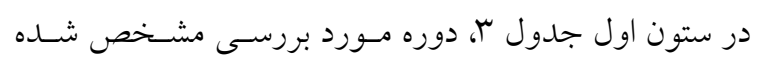

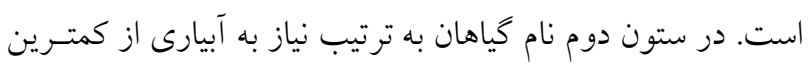

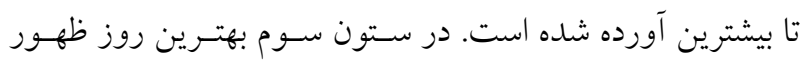

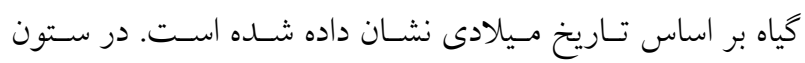
جهارم تعداد روزهاى مورد نياز براى رشد كامل گياه بعد از ظهور

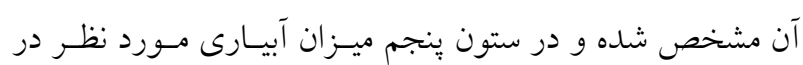

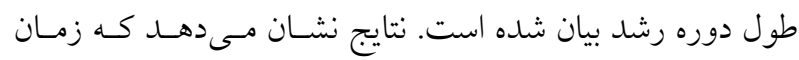

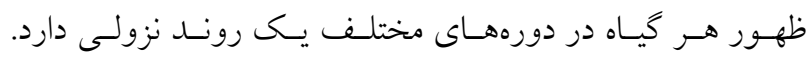

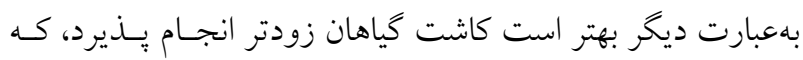

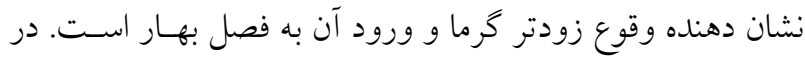

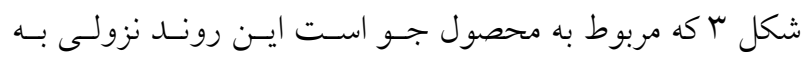
خوبى ديده مىشود، بهكونه اى كه زمان ظهور كياه در هر هـ سـال،

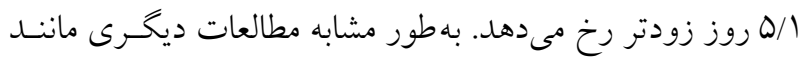

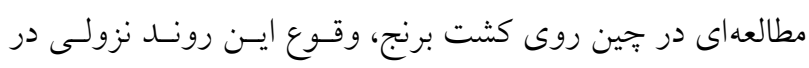

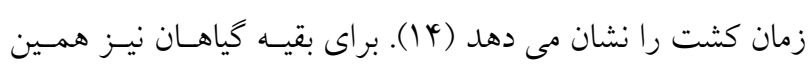


جدول س. نتايج بهدست آمده براى دشت اروميه

\begin{tabular}{|c|c|c|c|c|}
\hline آبيارى (ميلى متر) & دوره رشد از زمان ظهور (روز) & بهترين روز ظهور گياه & نام محصول & 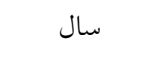 \\
\hline YIV & 1149 & I०Y & انغور & $r 0|V-r 0| 9$ \\
\hline DIT & 101 & 1.r & جِغندرقند & $r_{0}\left|V-r_{0}\right| q$ \\
\hline QTQ & 110 & lor & آفتابخر دان & $Y 0|V-Y 0| q$ \\
\hline DYQ & 114 & 10Y & 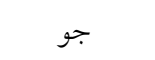 & $r 0\left|V-r_{0}\right| \varphi$ \\
\hline kyk & 110 & ITN & انخور & $Y 0|0-Y 0| Y$ \\
\hline$\Delta \Delta_{0}$ & 94 & 149 & جِغندرقند & $r \circ|0-Y 0| Y$ \\
\hline$\Delta \Delta Y$ & 94 & IrA & آفتابخر دان & $r \circ|0-r \circ| \varphi$ \\
\hline$\Delta \wedge 1$ & 99 & $1 K \Lambda$ & جو & $\left.r_{0}\left|Q-r_{0}\right|\right|^{4}$ \\
\hline YQO & 111 & IKT & انخور & $r \cdot \mid r-Y 0 \| r$ \\
\hline$\Delta \Delta \Lambda$ & 1.9 & lor & جغندرقند & $r_{0}\left|r-r_{0}\right| r$ \\
\hline DQY & $\Lambda V$ & Ifr & آفتابخر دان & $r 0\left|r-r_{0}\right| r$ \\
\hline 091 & $11 r$ & 100 & جو & $r 0|r-r 0| r$ \\
\hline щへ。 & 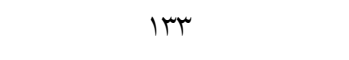 & 101 & انغور & $r_{0}\left\|1-r_{0}\right\|_{0}$ \\
\hline $0 \circ V$ & lor & 101 & جغندرقند & $r_{0} \mid 1-r_{0} \|_{0}$ \\
\hline$\Delta Y_{1}$ & 100 & 101 & آفتابحر دان & $r 0 \mid 1-r 010$ \\
\hline DYG & 109 & 101 & جو & $r_{0}\left\|1-r_{0}\right\|_{0}$ \\
\hline זN1 & (Tו & 114 & انخور & $r \circ \circ 9-Y_{0} \circ \Delta$ \\
\hline$\Delta V Q$ & 104 & 119 & جغندرقند & Y $0 \circ 9-Y_{0} \circ 00$ \\
\hline Q人 & 94 & int & آفتابخر دان & $r \circ \circ \varphi-r_{\circ} \circ \Delta$ \\
\hline 414 & 101 & $11 r$ & جو & $r \circ \circ G-r_{0} \circ \Delta$ \\
\hline EVD & 104 & 149 & انخور & Y००l-Y००० \\
\hline$\Delta \wedge \vee$ & 1。 & $14 \lambda$ & جغندرقند & 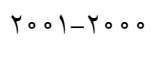 \\
\hline $9 \Delta Y$ & $\Lambda r$ & I ky & آفتابخر دان & Y००l-Y००० \\
\hline GKr & $\Delta r$ & 100 & جو & Y००।-Y००० \\
\hline rar & lor & 100 & انخور & $1999-1990$ \\
\hline YND & $11 \mathrm{~V}$ & 100 & جغندرقند & $1999-1990$ \\
\hline D.F & $11 \pi$ & 101 & آفتابخر دان & $1999-1990$ \\
\hline 011 & IrT & 100 & جو & $1999-1990$ \\
\hline Q.4 & IYY & 100 & انخور & $1991-1990$ \\
\hline$\Delta \wedge r$ & $\Lambda$ & 100 & جغندرقند & $1991-1990$ \\
\hline$\Delta \wedge \Lambda$ & 19 & $14 x$ & آفتابخر دان & $1991-1990$ \\
\hline 919 & 94 & $14 \lambda$ & جو & $1991-1990$ \\
\hline
\end{tabular}




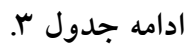

\begin{tabular}{|c|c|c|c|c|}
\hline آبيارى (ميلى متر) & دوره رشد از زمان ظهور (روز) & بهترين روز ظهور كياه & نام محصول & سال \\
\hline \&VA & $|4|$ & $11 r$ & انخور & $1919-19100$ \\
\hline DQY & 94 & 1ra & جغندرقند & $19 \wedge 9-19 \wedge 0$ \\
\hline 099 & $q 4$ & 149 & آفتابكر دان & $1919-19100$ \\
\hline 099 & 99 & $1 \% x$ & جو & $1914-1910$ \\
\hline KaY & rr & kro & انخور & $1911-1910$ \\
\hline$\Delta \Delta Y$ & 100 & Kro & جغندرقند & $1911-1910$ \\
\hline$\Delta \Delta Y$ & $\Lambda \mathrm{V}$ & 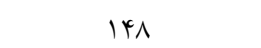 & آفتابخر دان & $1911-1910$ \\
\hline$\Delta \wedge V$ & 94 & 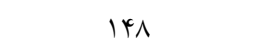 & جو & $1911-1910$ \\
\hline
\end{tabular}

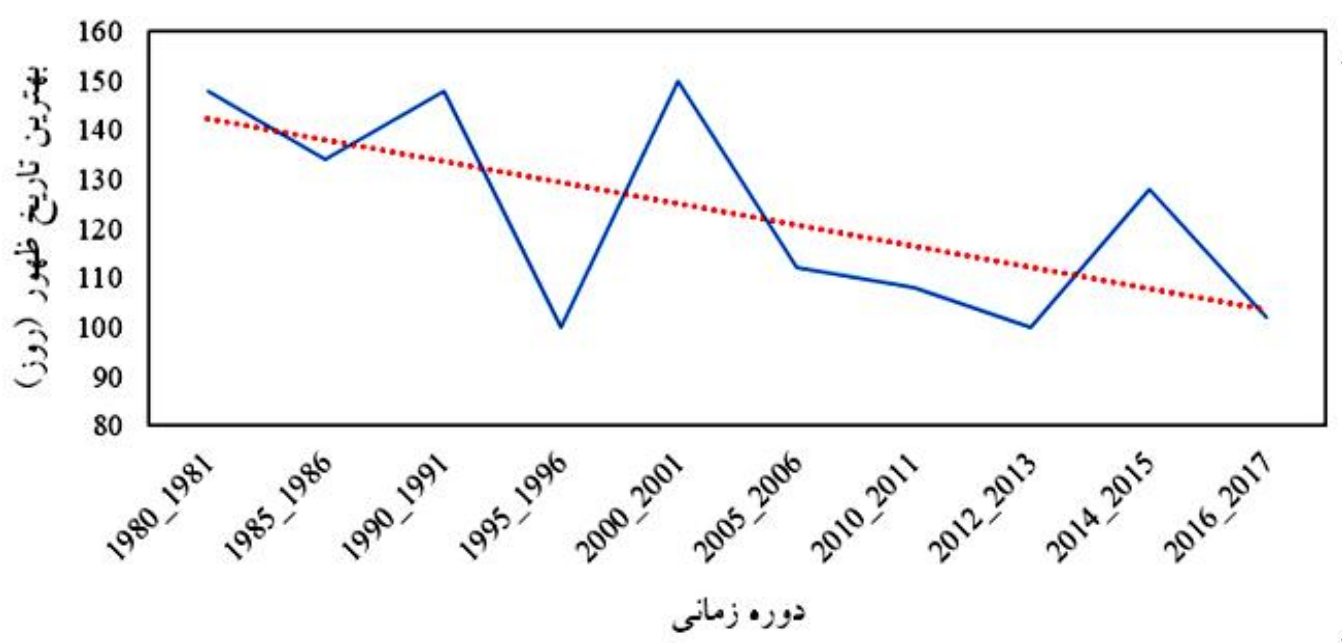

شكل س. تغييرات زمان بهينه ظهور در طول سالهاى مختلف براى جو

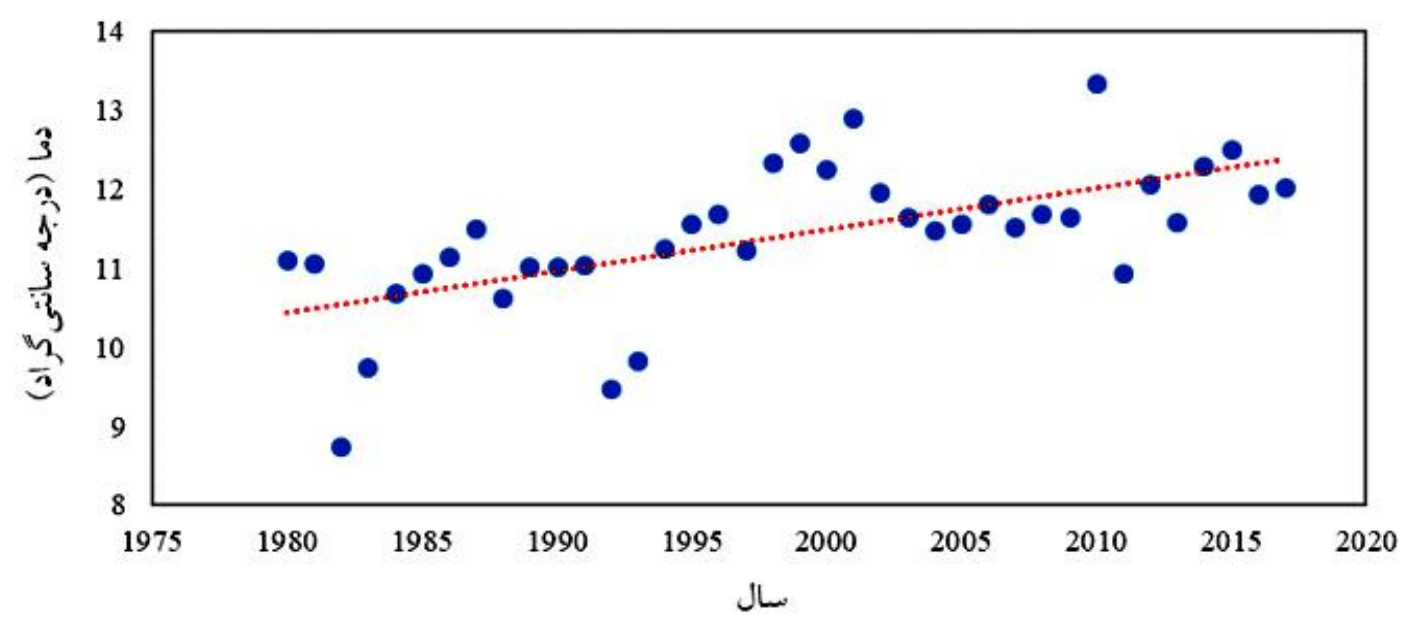

شكل F. H تغييرات دما از سال 191V تا 


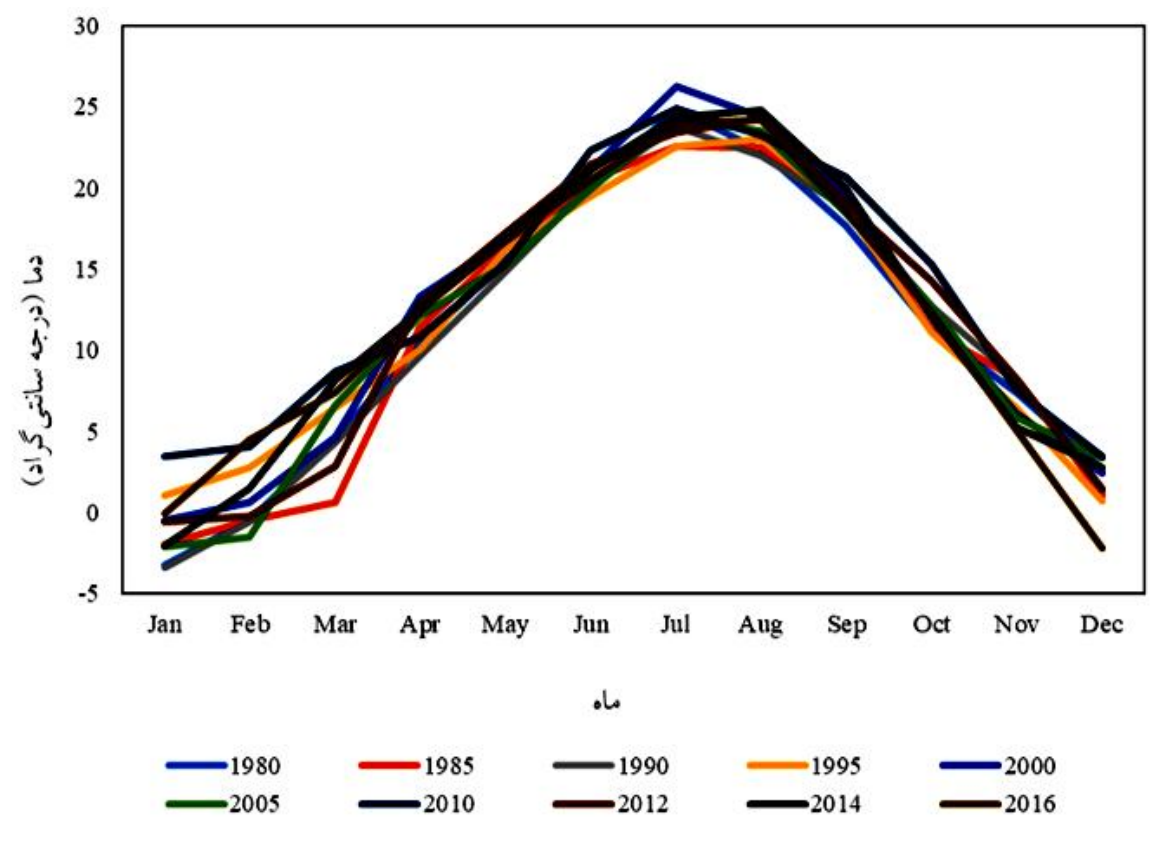

شكل ه. تغييرات ماهانه دما در دورههاى مختلف (رنكى در نسخه الكترونيكى)

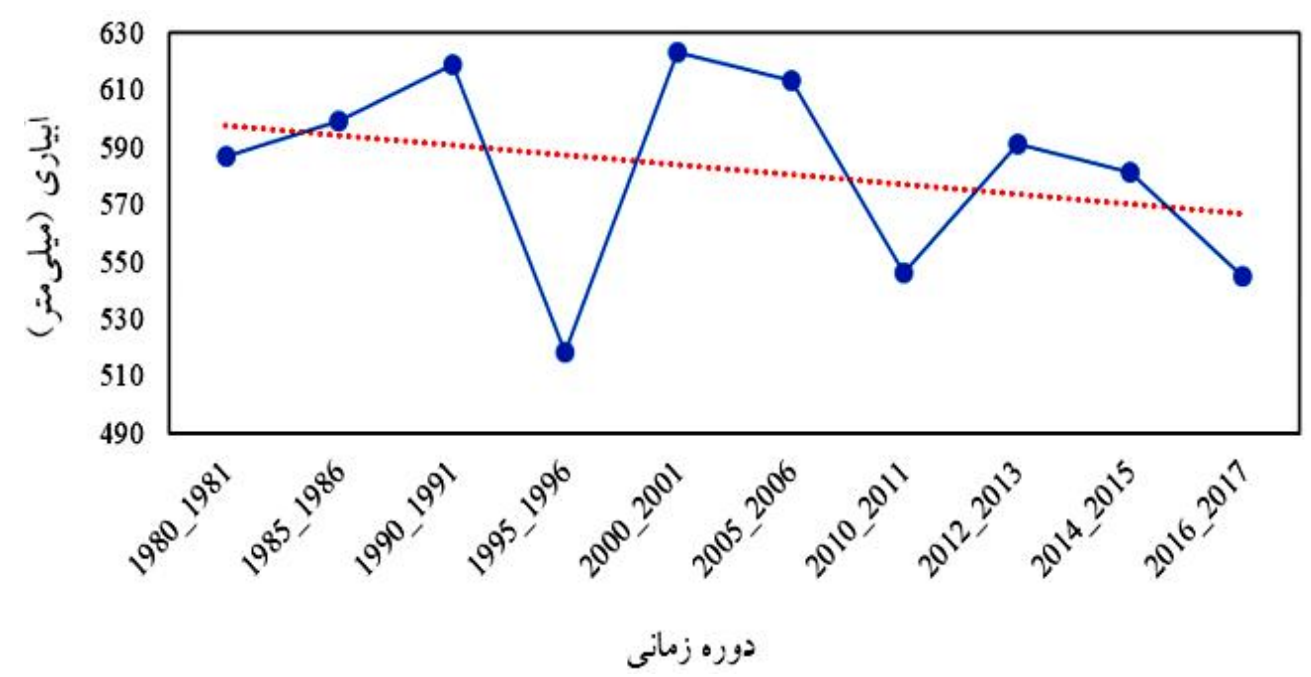

شكل 9. تغييرات آبيارى مورد نياز در دورههاى مختلف

همان طور كه در شكل 9 مشاهده مىشود، در طول زمان نياز بـهـاست، مىتوان بخش عظيمى از نياز آبسى كيـاه را از بـارشهـاى

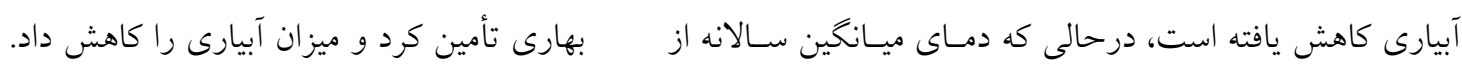

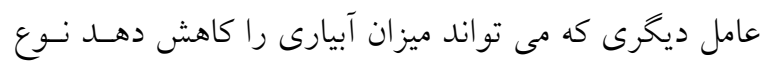

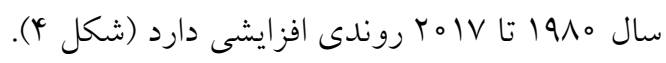

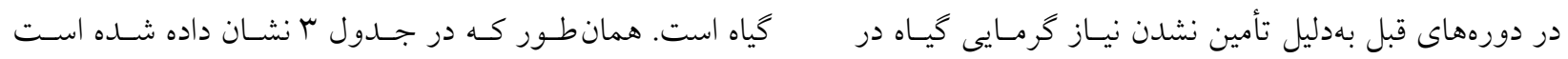

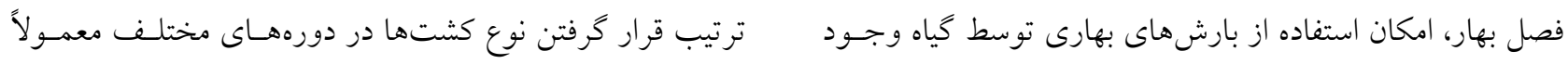

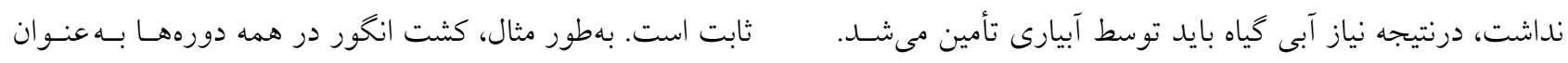

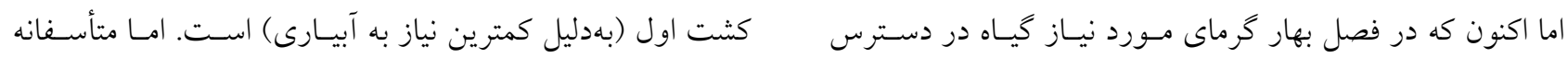




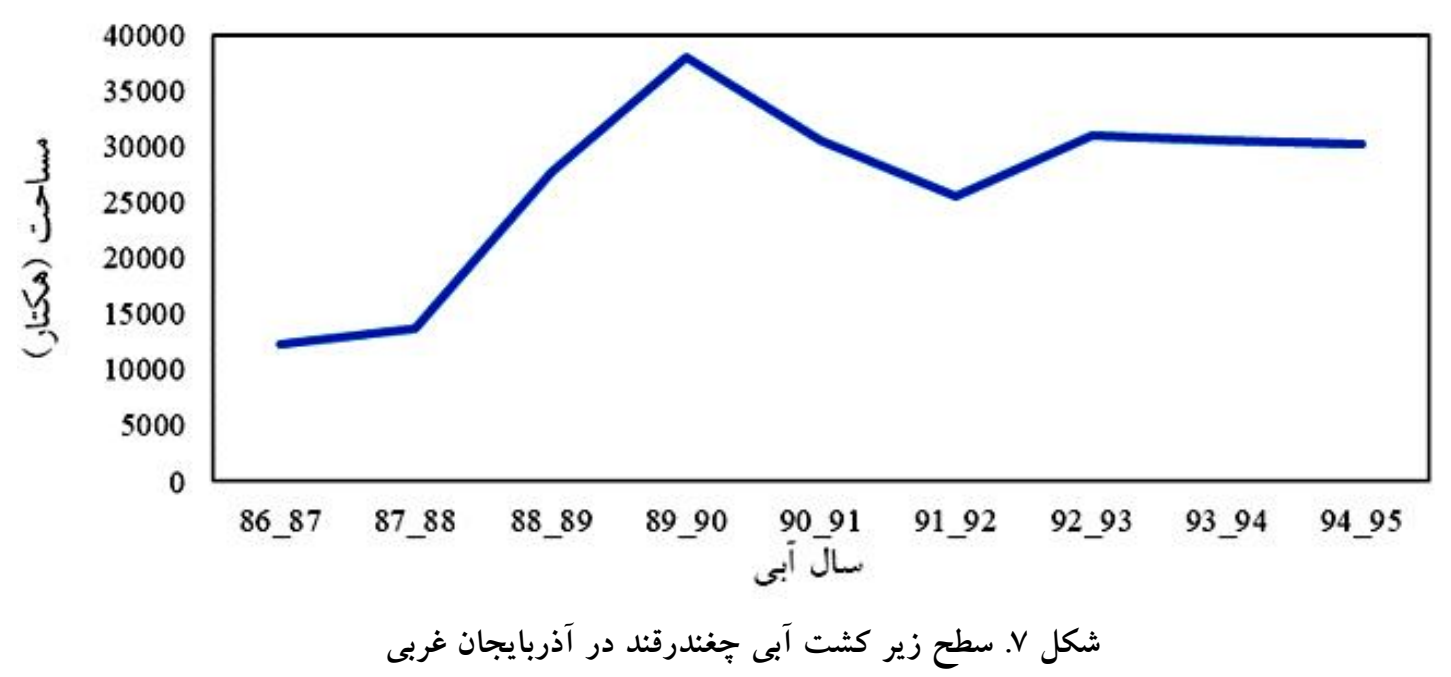

بارش هاى بهارى استفاده كند. درحالى كه جٍغندرقنــد در اروميـه

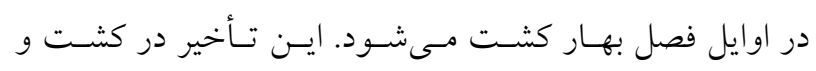

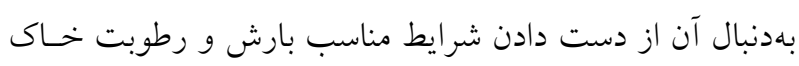

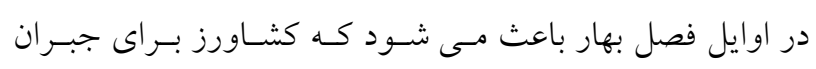

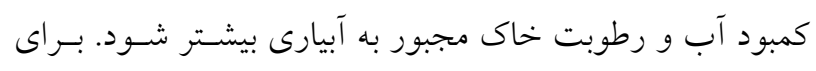

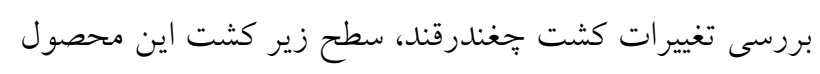

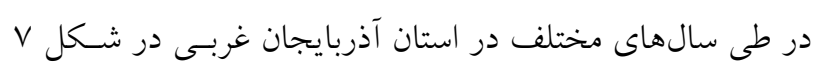

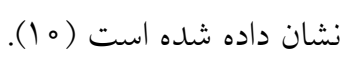

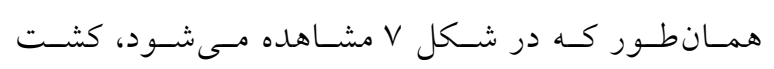

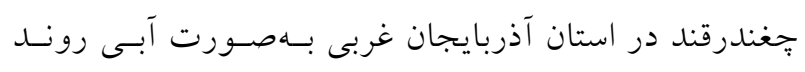

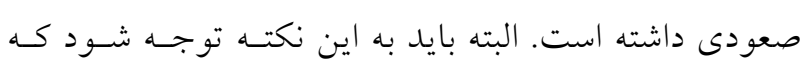
اطلاعات قابل دسترس در سـايت جهاد كشـاورزى از سـال

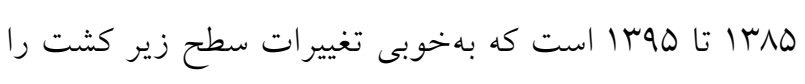

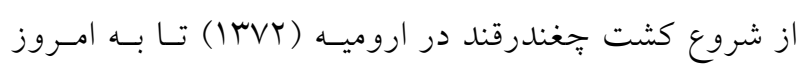

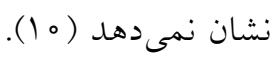

\section{نتيجه گيرى}

در اين يُزوهش با توجه به دو نياز آبى و گرمايى كيـاه، بهتـرين

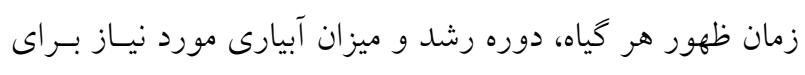

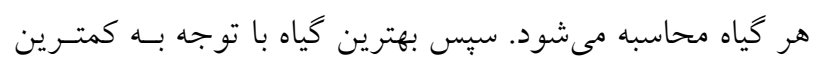

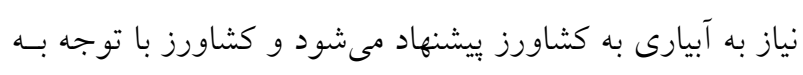

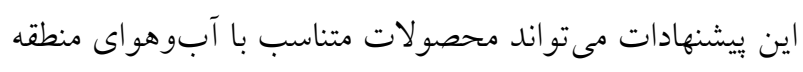

در جنند دهه اخير در اين منطقه شاهد تغيير كشت از انخـور بـهـ باغ هاى سيب بودهايم، باغهايى كه در طول سال به آبيـارى نيساز

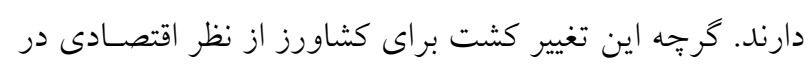

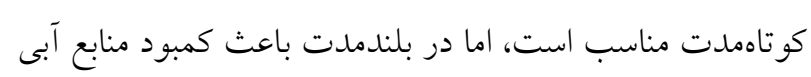

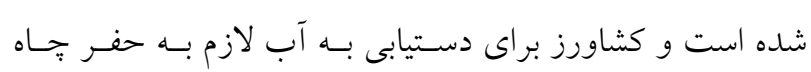

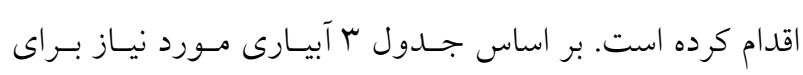

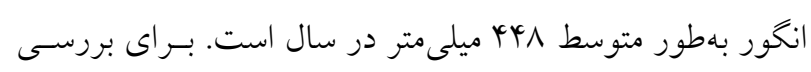

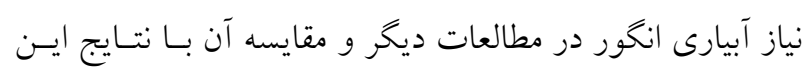

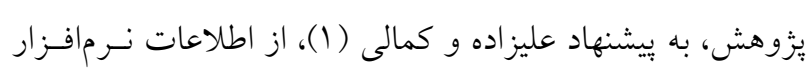

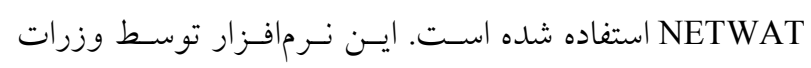
جهاد كشاورزى و سازمان هواشناسـى ايسران بـراى تعيـين نيـاز خالص آبيارى تمامى محصولات قابل كشت در كشور تهيه شده

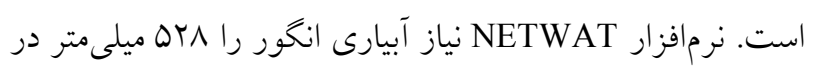

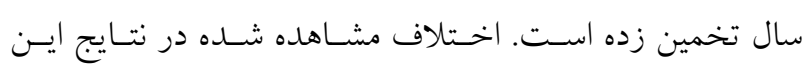

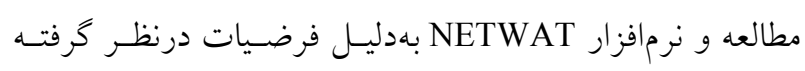

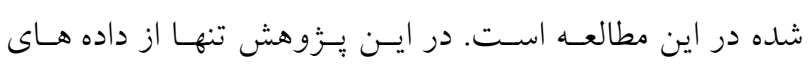

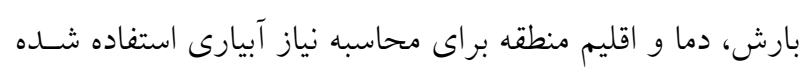

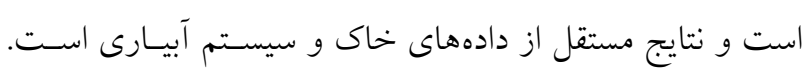
مثال مهم ديخر كشت جِغندرقند در اين منطقه است. همان طـور

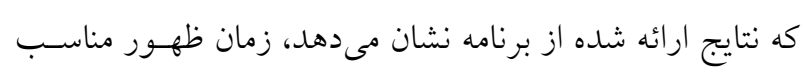

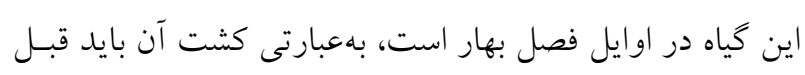

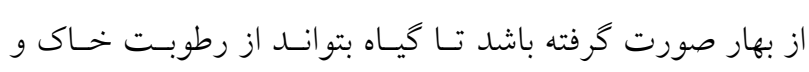




$$
\begin{aligned}
& \text { را كشت كند. دشت اروميه به عنـوان منطقـه مـورد مطالعـه ايسن بهسمت اوايل بهار حركت كرده است. بنابراين بهتر است كشت }
\end{aligned}
$$

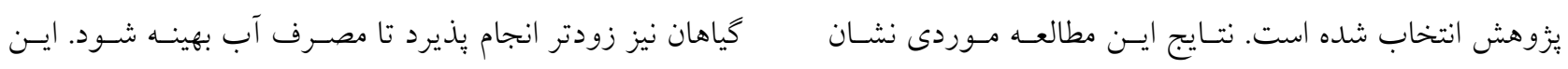

$$
\begin{aligned}
& \text { مى دهد كه بهترين زمان ظهور همه كياهان از سال •1911 تا سال مطالعه مسىتوانــ در راسـتاى اسـتفاده درسـت از منـابع آبسى و }
\end{aligned}
$$

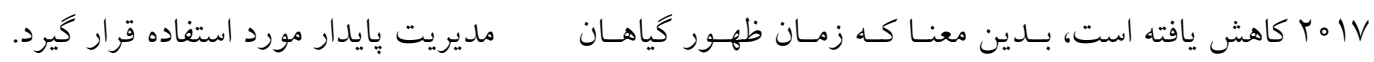

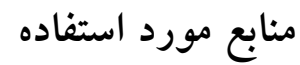

1. Alizadeh, A. and G. A. Kamali. 2007. Crops Water Requirements in IRAN. Imam Reza University, Mashhad.

2. AQUASTAT. 2016. AQUASTAT - FAO's global information system on water and agriculture. Available at: http://www.fao.org/aquastat/en/overview/methodology/water-use. Accessed March March 2020.

3. Brouwer, C. and M. Heibloem. 1986. Irrigation water management: irrigation water needs. Available online at: http://www.fao.org/3/s2022e/s2022e00.htm. Accessed 30 June 2020.

4. Easterling, D. R., G. A. Meehl, C. Parmesan, S. A. Changnon, T. R. Karl and L. O. Mearns. 2000. Climate extremes: observations, modeling, and impacts. Science 289(5487): 2068-2074.

5. Hamzehpour, N., S. M. A. Abasiyan and A. Majidi. 2016. The study of soil phosphorous status and availability in soils of Urmia Plain, Iran. Journal of Biodiversity and Environmental Sciences 8(5): 249-256.

6. Howe, G., J. St.Clair and R. Beloin. 2009. Seedlot selection tool. Available at: https://seedlotselectiontool.org/sst/. Accessed 10 January 2020.

7. Karimi, A. 2017. The effect of reducing $40 \%$ of allocated water for agriculture demand in the shahrchay dam to providing the Lake Urmia environmental demand. Urmia Lake Restoration Program, Urmia University, Urmia, I.R. Iran. (in Farsi)

8. Mardi, A. H., A. Khaghani, A. B. MacDonald, P. Nguyen, N. Karimi, P. Heidary, N. Karimi, P. Saemian, S. Sehatkashani, M. Tajrishy and A. Sorooshian. 2018. The Lake Urmia environmental disaster in Iran: A look at aerosol pollution. Science of the Total Environment 633: 42-49.

9. Menzel, A., N. Estrella and P. Fabian. 2001. Spatial and temporal variability of the phenological seasons in Germany from 1951 to 1996. Global Change Biology 7(6): 657-666.

10. Ministry of Jihad-e- Agriculture of Iran (MAJ). 2019. The annual agricultural statistics. Available at: https:/www.maj.ir/Index.aspx?page_=form\&lang=1\&PageID=11583\&tempname=amar\&sub=65\&methodName=S howModuleContent\#. Accessed 2 March 2020.

11. Moriondo, M. and M. Bindi. 2007. Impact of climate change on the phenology of typical Mediterranean crops. Italian Journal of Agrometeorology 3: 5-12.

12. Shokri, E., N. Shahnooshi, R. Mohammadzadeh and Y. Azarinfar. 2009. Study of factors affecting investment in Iranian agricultural sector. Journal of Agricultural Economics Researches 1: 107-121.

13. Taheri, M., M. Emadzadeh, M. Gholizadeh, M. Tajrishi, M. Ahmadi and M. Moradi. 2019. Investigating the temporal and spatial variations of water consumption in Urmia Lake River Basin considering the climate and anthropogenic effects on the agriculture in the basin. Agricultural Water Management 213: 782-791.

14. Tao, F., M. Yokozawa, Y. Xu, Y. Hayashi and Z. Zhang. 2006. Climate changes and trends in phenology and yields of field crops in China, 1981-2000. Agricultural and Forest Meteorology 138(1-4): 82-92.

15. Worldometers. 2019. World population (2020 and historical). Available at: https://www.worldometers.info/worldpopulation/\#table-historical. Accessed 2 March 2020.

16. Wuethrich, B., 2000. How climate change alters rhythms of the wild. Science 287(5454): 793-795.

17. Wypych, A., A. Sulikowska, Z. Ustrnul and D. Czekierda. 2017. Variability of growing degree days in Poland in response to ongoing climate changes in Europe. International Journal of Biometeorology 61(1): 49-59.

18. Zhang, X., M. A. Friedl, C. B. Schaaf and A. H. Strahler. 2004. Climate controls on vegetation phenological patterns in northern mid-and high latitudes inferred from MODIS data. Global Change Biology 10(7): 1133-1145.

19. Zargarpour, R. and A. Nurzad. 2010. A conceptual model of integrated water resource management for national water security. Water Resources Research 5(3): 1-13. (In Farsi).

20. Zheng, J., Q. Ge and Z. Hao. 2002. Impacts of climate warming on plants phenophases in China for the last 40 years. Chinese Science Bulletin 47(21): 1826-1831. 


\title{
Efficient Water Management under Climate Change in Urmia Plain
}

\author{
S. Moghim* and J. Rahmani ${ }^{1}$
}

(Received: April 22-2020 ; Accepted: August 26-2020)

\begin{abstract}
Improper water managements and overuse of surface water and groundwater mainly for agricultural purposes in Iran have led to the drying of many rivers and groundwater. Climate change adds an extra pressure on the water resources. These changes indicate the necessity of adjustment in water management plans. This study used hydroclimatic variables including precipitation and temperature in Urmia Plain to find appropriate crops that needed the minimum irrigation water. In addition, the best time for planting each crop is determined. To find the proper crops for the region, the daily water, as required for each crop, was calculated based on climate condition, crop type, and crop growth stage. The results indicates that grape could be the best crop for the region. In addition, early planting (e.g. in spring) reduced the irrigation water needed due to more rain and soil moisture in spring than summer, which could provide crop water requirement. On the other hand, the increased temperature in spring could satisfy heat units required for the fully grown plants like barley.
\end{abstract}

Keywords: Water resources management; Climate change; Agriculture; Crop pattern; Growing season, Water need

1. Water and Environmental Engineering Department, Civil Engineering College, Sharif University of Technology, Tehran, Iran.

Corresponding author, Email: moghim@sharif.edu 